\title{
UPAYA MENERAPKAN NILAI-NILAI PANCASILA DI MASA PANDEMI COVID-
}

\section{9}

\author{
Putri Nur Isnaini \& Dinie Anggraeni Dewi \\ Universitas Pendidikan Indonesia Cibiru \\ putrinuri@upi.edu
}

\begin{abstract}
Abstrak
Pancasila sebagai pedoman bangsa dan dasar negara sudah sepatutnya menjadi arahan kita dalam menjalankan kehidupan. Di masa Pandemi Covid-19 ini yang mana semua menjadi terasa asing tentunya Pancasila akan menjadi tuntunan kita. Maka dari itu Tujuan dari penelitian ini adalah utuk mengetahui dan menganalisis bagaimana penerapan nilai-nilai Pancasila di lingkungan Kampung Cikopo RW 07 Desa Bumiwangi, Ciparay, Kabupaten Bandung, Jawa Barat. Metode yang digunakan adalah pendekatan deskriptif kualitatif dengan sumber data adalah observasi lapangan ditambah dengan literatur lainnya yang diambil dari jurnal ataupun berita. Hasil dari penelitian ini adalah sebagian besar dari warga Kampung Cikopo RW 07 sudah mampu beradaptasi dengan kenormalan baru. Secara tidak langsung warga sudah mampu melaksanakan upaya penerapan nilai-nilai Pancasila di masa Pandemi Covid-19 ini. warga diharapkan mempunyai kesadaran untuk taat kepada peraturan atau kebijakan yang dibuat pemerintah, dengan selalu menerapkan protokol kesehatan dalam kehidupan sehari-harinya.
\end{abstract}

Kata kunci: Nilai-Nilai Pancasila, Pandemi Covid-19

\begin{abstract}
Pancasila as a guide for the nation and the foundation of the state should be our direction in carrying out life. During the covid-19 pandemic where everything feels strange, of course pancasila will be the guide of our life. Therefore the purpose of this research is to find out and analyze how the application of pancasila values in the environment of kampung cikopo rw 07, bumiwangi village, ciparay district, bandung regency, west java. The method used is a qualitative descriptive approach with the data source is field observation coupled with other literature taken from journals or news. From the results of this study are mostly from the residents of kampung cikopo rw 07, they have been able to adapt to new norms, indirectly the residents have been able to implement efforts to implement the values of pancasila during the covid -19 pandemic. Citizens are expected to have the awareness to obey the regulations or policies made by the government by always implementing health protocols in their daily lives.
\end{abstract}

Keywords: Pancasila Values, The Covid-19 Pandemic

\section{PENDAHULUAN}

Pancasila memiliki kedudukan sebagai dasar falsafah juga dasar negara dan pandangan hidup bangsa Indonesia. Menurut Octavian, W (2018) Pancasila yang berkedudukan sebagai dasar negara, pandangan dan falsafah hidup harus dipedomani bangsa Indonesia dalam proses penyelenggaraan kehidupan bermasyarakat, berbangsa dan bernegara dalam mewujudkan cita-cita proklamasi kemerdekaan. Nilai-nilai yang terkandung di dalamnya merupakan nilai luhur yang digali budaya bangsa dan memiliki nilai dasar yang diakui secara universal dan tidak akan berubah oleh perjalanan waktu. Oleh karena nilai yang terkandung pada pancasila adalah nilai budaya bangsa, sudah seharusnya nilai tersebut dapat terus dilestarikan. Untuk melestarikan nilai tersebut maka dibutuhkan aksi atau pengimplementasian dari setiap individu dalam kehidupan sehari-harinya (Nurgiansah, 2021b). Dalam mengimplementasikan nilai-nilai dari Pancasila tentunya selalu ada hambatan dan tantangannya. Jika dahulu pengimplemantasian dari nilai-nilai 
pancasila ini dirasakan belum optimal dari setiap warga negara. Hal ini dikarenakan banyaknya budaya luar yang silih berganti masuk menyebar luas ke Indonesia. Arus globalisasi tak semata-mata hanya menyebarkan hal yang positif pastinya ada hal negatif pula. Dibuktikan dengan banyaknya anak remaja khususnya yang lebih mencintai atau mengagumi bangsa lain. Sekarang selain adanya tantangan globalisasi, muncul tantangan baru yang datang kepada bangsa Indonesia. Hal itu adalah satu pandemi baru yang hadir di hampir semua belahan dunia (Nurgiansah, 2020b).

Pandemi ini disebabkan oleh virus corona Covid-19 yang awalnya berasal dari China. Virus ini kian menyebar luas ke penjuru dunia tak terkecuali Negara Indonesia. Bahkan tepat di satu taunnya Covid-19, angka positif yang terkena virus ini mencapai angka 1 juta di Indonesia. Dilansir dari kompas.com (24 Maret 21) virus corona terdapat beberapa varian, ada sekitar 4 varian baru dari virus corona. Yang pertama ada varian B.1.1.7 yang pertama kali dikonfirmasi di Inggris. Adanya varian B.1.1.7 yang masuk Indonesia juga membuat masyarakat khawatir. Terutama karena virus ini disebut lebih mudah menular. Kedua, ada B.1.351 atau 501Y V2 yang berawal dari Afrika Selatan. Menurut Organisasi Kesehatan Dunia (WHO), varian ini sudah menyebar ke lebih 30 negara lain. Yang ketiga ada Varian P.1 dari Brasil, pertama kali terdeteksi di pertengahan Januari, pada pelancong dari negara bagian Amazonas di Brasil yang pergi ke Jepang. varian baru virus corona lainnya adalah CAL.20C, yang mana saat ini menyumbang setengah dari kasus COVID-19 di California Selatan (Nurgiansah, 2021a).

Dengan banyaknya varian baru dari Covid-19 menjadikan suatu kekhawatiran bagi semua kalangan masyarakat. Bahkan varian baru dari Covid-19 sudah ada yang masuk ke Indonesia, hal ini menjadikan warga Indonesia kian panik akan virus ini. Selain itu, adanya pandemi yang dirasa belum surut ini terus menimbulkan dampak bagi kehidupan semua kalangan. Ditengah itu masyarakat pun dituntut untuk bisa beradaptasi dengan kebiasaan baru di era Pandemi ini. Perubahan kebiasaan di masa pandemi seperti ini sudah pasti dialami oleh semua masyarakat di dunia ataupun di Indonesia khususnya. Kebijakan-kebijakan baru untuk mengatasi permasalahan pandemi ini sudah disusun baik oleh jajaran elite politik. Tak jarang banyak pihak yang belum beradaptasi dengan baik. Lalu, Pancasila yang sudah seharusnya menjadi pedoman langkah kita bagaimana melaksanakannya di masa pandemi seperti ini. Dengan itu penulis, mencoba melihat atau mengkaji bagaimana upaya penerapan nilai dari Pancasila di salah satu daerah sekitar yaitu di Kampung Cikopo RW 07 Desa Bumiwangi, Ciparay, Kabupaten Bandung, Jawa Barat.

\section{METODE PENELITIAN}

Jenis penelitian ini yang digunakan adalah pendekatan deskriptif kualitatif. Penggunaan dari pendekatan ini bertujuan untuk mendeskripsikan perilaku atau sikap masyarakat dalam menerapkan nilai-nilai Pancasila di masa pandemi Covid-19. untuk lokasi penelitian yaitu di Kampung Cikopo RW 07 Desa Bumiwangi, Kecamatan Ciparay, Kabupaten Bandung, Jawa Barat. Instrumen perolehan data didapatkan dari proses pengamatan langsung di lapangan, wawancara kepada beberapa warga, dan melalui kajian jurnal atau berita yang relevan dengan pembahasan. Adapun langkah-langkah dalam penelitian ini adalah: (1) Studi Pendahuluan, dengan melihat fenomena yang ada pada masyarakat Indonesia pada umumnya dan masyarakat desa Bumiwangi khusunya, (2) untuk mendapatkan informasi yang akurat, 
penulis mulai melakukan pengamatan langsung di lapangan, melalukan wawancara secara non-formal kepada beberapa masyarakat dan ditambah dari kajian jurnal atau berita yang relevan dengan pembahasan, (3) penafsiran, setelah data terkumpul maka penulis menafsirkan dari hasil data tersebut dan menarik kesimpulan.

\section{HASIL PENELITIAN DAN PEMBAHASAN Hasil Penelitian}

Dalam setiap sila Pancasila mengandung nilai-nilai yang tetap bisa diterapkan atau diimplementasikan oleh warga sekalipun di masa pandemi.

\section{Pembahasan}

Adapun uraian dari setiap sila pancasila adalah sebagai berikut: Adapun upaya penerapan dari setiap sila-sila Pancasila adalah sebagai berikut:

1. Sila Ketuhanan Yang Maha Esa

Menurut Putri (2020) Nilai Ketuhanan ini berkaitan dengan keterkaitan individu dengan sesuatu yang dianggap sakral, suci, agung, dan mulia. Memahami ketuhanan sebagai pandangan hidup adalah mewujudkan masyarakat yang beketuhanan, yakni membangun masyarakat Indonesia yang memiliki jiwa maupun semangat untuk mencapai ridho Tuhan dalam setiap perbuatan baik yang dilakukannya.

Di masa pandemi Covid-19 ini warga dihimbau untuk melaksanakan ibadah di rumahnya masing-masing. Tetapi sekarang sesudah penerapan kenormalan baru, masjid sudah ramai dikunjungi lagi oleh jamaahnya. Di Kampung Cikopo RW 07, sholat Jum'at sudah dilakukan kembali di masjid dengan syarat menggunakan masker sesuai protokol kesehatan dari pemerintah. Madrasah untuk anak mengaji tentang agama pun sudah dapat dilaksanakan kembali dengan catatan anak menggunakan masker atau face shield.
Keterbatasan saat beribadah di masa pandemi ini dipandang ada hikmah dan pengajarannya (Nurgiansah, 2021c). Bahwa, hubungan dengan Tuhan tidak akan selalu linear dengan melakukan aktivitas ibadah di masjid, gereja, pura ataupun tempat ibadah lainnya. Yang diperlukan ialah mampu meciptakan relasi dan komunikasi yang khusus, dan ibadah bukan hanya sekadar hubungan manipulatif yang datang kepada Tuhan saat terdesak. (Setiawan,K : 2020)

2. Sila Kemanusiaan yang Adil dan Beradab Menurut Asmaroini (2016), nilai kemanusiaan ini artinya negara harus menjunjung tinggi harkat dan martabat manusia sebagai makhluk yang beradab. Dalam sila kedua ini mengandung juga nilai kesadaran, yaitu kesadaran sikap moral dan tingkah laku manusia yang harus berdasarkan kepada norma-norma dan kebudayaan baik terhadap diri sendiri, sesama manusia, ataupun pada lingkungannya.

Ismeliana (2020) berpendapat bahwa dalam nilai kemanusiaan, semua masyarakat memiliki hak untuk mendapatkan perlindungan dan bantuan adil dari pemerintah. Oleh karena itu, warga mendapatkan satu konsekuensi dari itu yaitu melaksanakan kewajiban untuk patuh hukum dan kebijakan yang dikeluarkan oleh Pemerintah di masa pandemi ini. Dari hasil survei Badan Pusat Statistika (BPS) tentang kondisi sosial demografi dampak COVID-19 menunjukan bahwa anjuran untuk jaga jarak (physical distancing) dipahami secara mendetail oleh $87 \%$ responden, dan dilaksanakan oleh 72\% masyarakat. Namun, Kesadaran untuk menaati kebijakan Pemerintah belum terlihat secara menyeluruh pada warga RW 07 Kampung Cikopo. Terkadang ada masyarakat yang masih belum sadar bahwa menggunakan masker saat keluar rumah itu penting. Hal ini ditunjukkan saat 
warga pergi ke pasar tumpah yang notabenenya banyak bertemu dengan orang, sebagian warga masih ada yang tidak memakai masker dan menjaga jarak.

\section{Sila Persatuan Indonesia}

Nilai persatuan indonesia, mengandung makna bahwa negara sebagai penjelmaan dari sifat dan kodrat manusia yang monodualis yang artinya manusia sebagai makhluk individu dan makhluk sosial. Negara yang merupakan suatu persekutuan hidup bersama diantara elemen pembentuk negara yang berupa suku, kelompok, ras, golongan, ataupun kelompok agama. Maka dari itu, perbedaan merupakan kodrat manusia dan ciri khas dari elemen yang membentuk negara. Perbedaan bukan untuk ditujukan menjadi suatu konflik dan permusuhan melainkan harus diarahkan pada suatu sintesa yang saling menguntungkan. (hanafi:2018).

Di masa pandemi ini, rasa nasionalisme, kekeluargaan dan saling gotong royong sangat dibutuhkan sekali. Masyarakat mampu saling bahu membahu dalam menghadapi pandemi dengan memberikan bantuan secara materil atau non materil juga do'a pada saudarasaudara kita. Hal ini sangat terlihat di lingkungan masyarakat RW 07 , khusunya saat ada Shalat Jum'at di Masjid Nurul Hidayah. Sesudah melaksanakna Shalat biasanya para jamaah diberikan nasi box oleh para orang dermawan tanpa melihat dia golongan mana atau status sosialnya. Bersatu dalam kepatuhan pada ketentuan hukum dalam rangka menangani pandemi Covid ini, sikap empati harus mampu melahirkan persatuan gotong royong untuk menyelesaikan masalah. Saling membantu, berbagi, dan saling berkolaborasi tanpa melihat ras, suku dan agama merupakan makna dari sila ketiga (Widiyanti:2020).

Selain memberikan bantuan secara materil, meningkatkan gotong royong di masa pandemi adalah dengan selalu menaati apa yang sudah ditentukan oleh pemerintah. Hal ini ssejalan dengan pemikiran Kurnia, bahwa setiap warga negara indonesia wajib untuk menjalankan peraturan yang sudah dibuat oleh pemerintah. Karena, pada dasarnya peraturan itu dibuat untuk kepentingan juga kebaikan bersama.

4. Sila Kerakyatan yang Dipimpin oleh Hikmah Kebijaksanaan dalam Permusyawaratan Perwakilan

Pada hakikat manusia sebagai makhluk sosial tentunya membutuhkan hidup berdampingan bersama orang lainnya. Di dalam interaksi bersama orang lain tersebut biasanya terjadi kesepakatan, saling menghargai satu sama lain dengan tujuan dan kepentingan bersama. Hal itu pun sejalan dengan makna dari Nilai kerakyatan pada Pancasila. Menurut Danniarti (2017), nilai kerakyatan mengandung makna suatu pemerintahan itu dari rakyat, oleh rakyat dan untuk rakyat yang dilakukan dengan musyawarh mufakat melalui lembaga-lembaga perwakilan rakyat.

Menurut Ismelina (2020) nilai sila keempat ini memiliki arti bahwa keputusan atau kebijakan yang diambil adalah hasil musyawarah juga keputusan bersama yang selanjutnya dilaksanakan bersama-sama demi keselamatan dan kepentingan bangsa itu sendiri. Penerapan nilai ini disaat pandemi adalah bagaimana tokoh-tokoh masyarakat mampu melakukan koordinasi dalam rangka memahamkan masyarakat mengenai pentingnya untuk menjalankan himbauan dari pemerintah supaya tidak melakukan aktivitas di luar rumah. (Achmadi:2020).

Penerapan seperti itu sangat dirasakan di wilayah RW 07 Kampung Cikopo, terlihat ketika ada kegiatan yang sekiranya akan mengumpulkan banyak orang. Para tokoh masyarakat selalu 
menghimbau agar selalu menggunakan masker dan tidak lupa mencuci tangan terlebih dahulu ataupun menggunakan hand sanitizer. Pada Idul Adha $1441 \mathrm{H}$, para warga yang ikut melalukan kegiatan penyembelihan hewan qurban selalu diingatkan oleh Ketua RT selaku pemimpin di kalangannya untuk selalu menggunakan masker bahkan hingga disediakan masker dari panitianya.

\section{Sila Keadilan Sosial Bagi Seluruh Rakyat Indonesia}

Dalam sila kelima keadilan sosial bagi seluruh rakyat memiliki makna bahwa ada keadilan pribadi dan sosial. Menurut khoiriah, keadilan pribadi ialah keadilan individu atau perseorangan dan keadilan sosial adalah keadilan secara bersamasama. Seluruh rakyat Indonesia mendapatkan hak keadilan dalam hukum, ekonomi, politik, dan sosial budaya tanpa ada keberpihakan pada kelompok atau pribadi tertentu.

Sila keadilan sosial bagi seluruh rakyat Indonesia memiliki makna bahwa negara harus melakukan masyarakatnya secara adil (Nurgiansah, 2020a). Di masa pandemi seperti ini, keadilan penanganan masyarakat tidak boleh dlakukan secara membeda-bedakan atau mengkotakkotakan. GKR Hemas dalam radarjogja mengungkapkan bahwa " dalam masa new normal ini jangan sampai hanya kelompok orang kaya saja yang hidup, tidak kelaparan dan mendapat fasilitas kesehatan, rakyat kecil juga harus mendapat kesempatan yang sama." Artinya, bahwa setiap elemen masyarakat berhak mendapatkan kelayakan hidup di saat pandemi ini tidak hanya untuk orang kaya (Nurgiansah \& Al Muchtar, 2018).

Di masa pandemi seperti ini, masyarakat yang berada dalam kelas menengah ke bawah banyak mendapatkan bantuan langsung dari pemerintah yang mana nantinya akan membantu beban ekonomi keluarganya. Bantuan ini diberikan dalam bentuk bantuan sembako dan ada bantuan yang langsung secara tunai. Selain itu pemerintah meluncurkan program kartu pra kerja dengan anggaran hingga 20 Triliun Rupiah. Program ini tidak di spesifikasikan kepada korban PHK tetapi kepada semua pengangguran termasuk yang baru menyelesaikan pendidikan formal. (Livana, dkk:2020)

Bantuan-bantuan tersebut sangat dirasakan oleh para warga RW 07 Kampung Cikopo. Salah satu sasaran yang penting adalah lansia. Seperti yang dialami oleh Nenek Encih, ia mendapatkan bantuan beras yang diberikan oleh Desa. Selain itu banyak juga para pengangguran yang mendaftar program Kartu PraKerja, sehingga mereka mendapatka bantuan Uang Tunai. Selain dari Prakerja ada bantuan dari BPJS Ketenagakerjaan yang diberikan kepada para karyawan pabrik. Bantuan baik berupa BLT ataupun bantuan sukarela dari sekelompok orang nyatanya sangat membantu. Hal ini juga yang diuraikan oleh Wowiling (2021), bahwa bantuan dari pemerintah mampu membantu kehidupan masyarakat dalam kelangsungan hidupnya. Hal ini disebabkan karena di masa pandemi Covid-19 ini banyak masyarakat yang kehilangan pekerjaannya yang memberikan dampak langsung pada kehidupannya. Bantuan ini mampu membuat masyarakat miskin tidak menjadi lebih miskin dan tak punya apaapa.

Selain para warga yang aktif mendaftarkan untuk mendapatkan bantuan. Peran Ketua RT atau tokoh masyarakat lainnya harus sangat aktif. Misalnya pada RT 04 dan 03 bisa saling berkoordinasi dalam menyebarkan bantuan. Ketika di RT 03 mendapatkan lebih setelah dibagi, maka akan dibagikan kepada Warga RT 04 yang masih kekurangan. Hal ini pun sangat sesuai 
dengan nilai keadilan bagi seluruh rakyat Indonesia tanpa membeda-bedakan.

Pandemi Covid-19 ini memberikan peluang besar bagi seleruh elemen masyarakat untuk bisa mewujudkan keadilan sosial bagi semua. Pemerintah di masa ini meluncurkan berbagai kartu untuk menolong masyarakat ekonomi rendah supaya mereka masih bisa bertahan hidup di tengah kemelut pandemi ini.

\section{KESIMPULAN}

Pancasila sebagai pandangan hidup bangsa dan dasar negara tentunya mampu mengatur kehidupan berbangsan dan bernegara. Pancasila juga mampu mengatur kegiatan atau aktivitas hidup di masa pandemi covid-19. Nilai-nilai dari setiap sila Pancasila terbukti bisa relevan dalam setiap keadaan. Dimulai dari nilai Ketuhanan, dimana setiap masyarakat mampu melaksanakan beribadah sesuai agamanya masing-masing di rumah dan tidak mengurangi dari pahala ibadah itu senidiri malah dirasa menjadi lebih intim hubungan Tuhan dengan Hambanya. Pada nilai kemanusiaan, setiap manusia harus diakui dan diperlakukan sesuai harkat dan martabatnya sebagai Makhluk Tuhan YME. Maka itu, setiap masyarakat berhak mendapatkan perlindungan dan bantuan yang adil dari pemerintah ataupun masyarakat lainnya di masa pandemi ini. Nilai persatuan adalah nilai yang paling mendasar di masa pandemi ini, bagaimana setiap elemen masyarakat mampu saling bersatu dan bergotong royong untuk menangani pandemi Covid-19 dan dampaknya. Masyarakat yang mampu menghargai ketentuan-ketentuan elite politik atau pemerintah dalam rangka menangani Covid-19 merupakan salah satu bagaimana implementasi atau cara menerapkan nilai permusyawaratan dan perwakilan di masa pandemi ini. saling memberi bantuan tanpa membedabedakan status kepada masyarakat adalah contoh penerapan nilai keadilan sosial di masa pandemi. Pemerintah dan masyarakat harus bisa bersinergi untuk membantu masyarakat yang khususnya terdampak karena adanya pandemi ini dengan memberikan bantuan demi kelangsungan hidupnya.

Pandemi covid-19 ini tidak tahu kapan akan berakhir. Namun, diharapkan setiap masyarakat mampu menjalankan nilai-nilai Pancasila secara menyeluruh dengan selalu memperhatikan protokol kesehatan. Saling bersatu padu untuk bisa memberikan bantuan kepada masyarakat yang terdampak adalah tugas kita semua. Menghargai keputusan pemerintah merupakan salah satu ikhtiar kita untuk tidak menambah kasus positif virus ini. dan yang paling terpenting, ialah selalu berdo'a agar pandemi ini segera berakhir dan kita bisa melakukan aktivitas seperti biasanya.

\section{DAFTAR PUSTAKA}

Achmadi, R. Z., \& Muhibbin, A. (2020). Implementasi Nilai-Nilai Pancasila Pada Masa Pandemi Covid 19 (Studi Kasus pada Angkatan Muda Partai Golkar di Kecamatan Gondangrejo Kabupaten Karanganyar) (Doctoral dissertation, Universitas Muhammadiyah Surakarta).

Asmaroini, A. P. (2016). Implementasi Nilai-Nilai Pancasila Bagi Siswa Di Era Globalisasi. Citizenship Jurnal Pancasila dan Kewarganegaraan, 4(2), 440-450.

BPS RI (2020). Hasil Survei Sosial Demografi Dampak Covid-19. Jakarta: BPS RI.

Danniarti, R. (2017). Implementasi Nilai-Nilai Pancasila Sebagai Pendukung Tumbuh Kembang Wawasan Kebangsaan pada Mata Pelajaran PPKn di SMP Negeri 7 Palembang. JMKSP (Jurnal Manajemen, Kepemimpinan, dan Supervisi Pendidikan), 2(2), 187-202. 
Hanafi, H. (2018). HAKEKAT NILAI PERSATUAN DALAM KONTEKS INDONESIA (Sebuah Tinjauan Kontekstual Positif Sila Ketiga Pancasila). Jurnal Ilmiah Pendidikan Pancasila dan Kewarganegaraan, 3(1), 56-63.

Ismelina, M. (2020). Merenungkan Nilai-Nilai Pancasila Dalam Pandemi Corona. Jakarta: Kompas.Com.

Kurnia, A.N. Meningkatkan Semangat Gotong Royong Bagi Warga Negara Indonesia Dalam Menghadapi Pandemi Covid-19.nn.

Livana, P. H., Suwoso, R. H., Febrianto, T., Kushindarto, D., \& Aziz, F. (2020). Dampak pandemi COVID-19 bagi perekonomian masyarakat desa. Indonesian Journal of Nursing and Health Sciences, 1(1), 37-48.

Nurgiansah, T. H. (2020a). Fenomena Prostitusi Online Di Kota Yogyakarta Dalam Persfektif Nilai Kemanusiaan Yang Adil Dan Beradab. Jurnal Kewarganegaraan, 17(1), 27-34. https://doi.org/10.24114/jk.v17i1.14208

Nurgiansah, T. H. (2020b). Filsafat Pendidikan. In Banyumas: CV Pena Persada.

Nurgiansah, T. H. (2021a). Partisipasi Politik Masyarakat Sleman di Masa Pandemi Covid-19 dalam Konteks Pendidikan Kewarganegaraan. Jurnal Civic Hukum, 6(1), 1-9.

Nurgiansah, T. H. (2021b). Pendidikan Pancasila. In Solok: CV Mitra Cendekia Media.

Nurgiansah, T. H. (2021c). Workshop Media Pembelajaran Berbasis Teknologi Informasi Dalam Menghadapi Revolusi Industri 4.0. Jurnal Pengabdian Untuk Mu NegeRI, 5(1), 1-4.

Nurgiansah, T. H., \& Al Muchtar, S. (2018). Development of Student Awareness through Student Learning Model Jurisprudential in Citizenship Education. ATLANTIS PRESS, 251(Acec), 670-674. https://doi.org/10.2991/acec-18.2018.150

Octavian, W. A. (2018). Urgensi Memahami Dan Mengimplementasikan Nilai-Nilai Pancasila Dalam Kehidupan Sehari-Hari Sebagai Sebuah Bangsa. Jurnal Bhinneka Tunggal Ika, 123128.

Putri, H. (2020). Penerapan Nilai-Nilai Dalam Kehidupan Sehari-Hari Dan Sebagai Pendidikan Karakter Pancasila. Makalah.

Setiawan, K. U. (2020). Upaya Menerapkan Nilai-Nilai Luhur Pancassila Selama Dan Sesudah Pandemi Covid-19. Diligentia:Journal Of Theology And Christian Education, 78-89.

Wowiling,R.(2021). Peran Pemerintah Desa Dalam Penyaluran Bantuan Langsung Tunai Pada Masyarakat Di Masa Pandemi Covid-19 Di Kecamatan Maesaan Kabupaten Minahasa Selatan. Jurnal Politico, 10(4).

Widiyanti, R. A. (2020). Implementasi Nilai-Nilai Dasar Pancasila Dalam Dan Pasca Covid 19 Demi Menyongsong Era Adaptasi Kebiasaan Baru (Akb). Jurnal Pendidikan Sosial Keberagaman, 7(2). 